\title{
THE ROLE OF INTERNATIONAL AND PROFESSIONAL ORGANISATIONS' IN DEFINING STATE-OWNED ENTERPRISES
}

\author{
Ioana Andreea Ciolomic ${ }^{1}$ \\ Ioana Natalia Beleiu ${ }^{2}$
}

DOI: https://doi.org/10.31410/ITEMA.2020.83

\begin{abstract}
State-owned enterprises (SOEs) have an essential role in national economies worldwide, but regardless of their acknowledged contribution to the global markets, divergent opinions and approaches can be observed when defining and characterizing these entities. On the other hand, international organizations such as OECD, International Monetary Fund, European Commission, United Nations, World Trade Organizations, World Bank, Asian Development Bank, and professional organizations such as IPSASB and Chartered Institute of Management Accountants have an essential role in SOEs' activity. One of the biggest challenges that professional bodies have nowadays is to find a unique definition to match the need of practitioners and capture the complexity of SOEs. Even if there can be identified some common approaches between academicians, international, and professional organizations, there are some delicate areas that require substantial efforts for clarifications. The paper addresses this topic, aiming to clarify the main aspects concerning the definition of SOEs from international and professional organizations' points of view based on qualitative research methods.
\end{abstract}

Keywords: State-owned enterprises, International and professional organisations, Governance.

\section{INTRODUCTION}

$\mathrm{R}$ eforms in public management represent a global trend (Ongaro and Valotti, 2008), being frequent when regulations are not correlated with the business world reality or instructions regarding their implementation are missing. Unfortunately, in most countries, the current legislation referring to state-owned enterprises (SOE) is inadequate, adjusting, and restructuring SOEs being a necessity determined by the market and technological changes (Kloviene and Gimzauskiene, 2014).

SOEs' importance strongly increased in the recent period due to a stringent need for effective, efficient, and high-quality public services (Papenfuss and Schmidt, 2015). Recently, both researchers and practitioners focus on aspects regarding good governance to increase organisational efficiency. Christiansen (2011) underlines the importance of SOEs by presenting statistical data that create an overview of the Organisation for Economic CoOperation and Development (OECD) reporting countries' situation in the year 2008/2009: 2,057 enterprises, employing over 4 million people and with an estimated value exceeding 1.3 trillion US dollars. 
The research presented in this article is mainly qualitative. It aims to clarify the main aspects concerning SOEs' definition from international and professional organizations' point of view. One conclusion of the study is that clearly defined concepts should contribute to a better understanding of the SOEs concept and contribute to good governance by enhancing the quality, consistency, and transparency of government' actions.

The paper's remaining sections are organized as follows: methodological aspects, findings and discussions of SOE definitions used by international and professional organisations, and conclusions of the conducted study.

\section{METHODOLOGY AND RESEARCH QUESTION}

International and professional organisations have divergent opinions and approaches when defining and characterizing state-owned enterprises. One of the biggest challenges that professional bodies have nowadays is to find a unique definition to match the need of practitioners and capture the complexity of SOEs. The purpose of the paper is to create a comprehensive view of the topic of SOEs' definitions used by international and professional organisations related to emerging issues like governance, performance, accounting, and accountability. The study's research question is: How do international and professional organisations define SOEs?

The methodology is in line with the interpretative perspective and pays particular attention to the meanings behind SOE. The data collection is based on content analysis of documents issued by worldwide recognised international organisations like OECD, International Monetary Fund (IMF), European Commission (EC), United Nations (UN), World Trade Organisations (WTO), World Bank (WB), Asian Development Bank (ADB) and professional organisations such as IPSASB and Chartered Institute of Management Accountants (CIMA). For each organisation, the table below presents the documents used for content analysis.

Table 1. Documents used for content analysis

\begin{tabular}{|c|c|c|}
\hline $\begin{array}{l}\text { International } \\
\text { organisation }\end{array}$ & Year & Document \\
\hline OECD & $\begin{array}{l}2005 \\
2014\end{array}$ & $\begin{array}{l}\text { Corporate governance of state-owned enterprises: A } \\
\text { survey of OECD countries } \\
\text { OECD Guidelines on Corporate Governance of State- } \\
\text { Owned Enterprises - Draft for Public Comment }\end{array}$ \\
\hline $\begin{array}{l}\text { International Monetary } \\
\text { Fund }\end{array}$ & 2014 & Government Finance Statistics Manual \\
\hline European Commission & 2012 & $\begin{array}{l}\text { EUROSTAT Foreign Affiliates Statistics } \\
\text { Recommendation Material }\end{array}$ \\
\hline United Nations & $\begin{array}{l}2008 \\
2014\end{array}$ & $\begin{array}{c}\text { System of National Accounts } \\
\text { World Investment Report 2014: Investing in the SDGs: } \\
\text { An Action Plan }\end{array}$ \\
\hline IPSASB & 2012 & $\begin{array}{c}\text { Handbook of International Public Sector Accounting } \\
\text { Pronouncements - Vol. I, II }\end{array}$ \\
\hline $\begin{array}{l}\text { World Trade } \\
\text { Organisation }\end{array}$ & 1994 & The General Agreement on Tariffs and Trade \\
\hline
\end{tabular}

Source: Author's projection 
The selected documents are analysed to identify critical elements used in defining SOEs. The organisations were selected based on their interest regarding the topic of SOEs.

\section{FINDINGS AND DISCUSSIONS OF SOE DEFINITIONS USED BY INTERNATIONAL AND PROFESSIONAL ORGANISATIONS}

The concept of SOE is at the top of debates of international and professional organizations such as the OECD, IMF, EC, UN, WTO, WB, ADB, CIMA, and IPSASB. Baring this in mind, to achieve the paper's purpose, we analysed the definitions provided by these institutions. These organisations, except WB, deal with SOEs without considering the level of government (state, regional and local government) while acknowledging the existence of different levels and forms of ownership and control. On the other hand, the World's Bank toolkit focuses on SOEs at the national level. Even though this guideline does not cover municipal and local level SOEs, they admit that many of the concepts and approaches are relevant for them as well. CIMA (professional organisation) and $\mathrm{ADB}$ (international organisation) are involved in projects regarding SOEs, but none of their actions aim to define SOEs, the primary constraint of our methodology. Based on this imposed restriction, these organisations could not be included in our analysis.

Readjustment and restructure of state-owned sectors in the context of markets globalization, technological reforms, and deregulation of previously monopolistic markets determined the OECD to initiate various projects in this field since 2003. The most relevant projects are "Privatizing State-Owned Enterprise, An Overview of Policies and Practices in OECD Countries" 2003 and "Corporate Governance of State-Owned Enterprises: A Survey of OECD Countries", 2005.

In the OECD Guidelines on Corporate Governance of SOEs, the terms used are "state-owned enterprises", defined as "enterprises where the state has significant control, through full, majority, or significant minority ownership" (OECD 2005, 11). The definition provided by OECD since 2005 is not restrictive, covering two key elements: control and ownership. Although it appears relatively straightforward, several countries had responded in various manners when they applied the OECD definition in their national legislation:

- Countries that took over the conditions provided by OECD, some even adding other critical elements as legal form or activity (objectives)- for example, Australia, Austria, Belgium, Czech Republic, Bulgaria, Romania, Italy;

- Countries that modified the conditions provided by OECD, adding the percentage of ownership/votes - for example, Estonia, Greece (requires more than 50\% of share capital), Hungary (companies in which the state owns at least 10\%), Slovenia (the government owns directly or indirectly at least $25 \%$ plus one vote of the total capital).

In May 2014, the OECD developed a new draft for public comments on the OECD Guidelines on Corporate Governance of State-Owned Enterprises, with a noticeably different approach related to SOEs' concept from the previous version. According to the new guidelines, the SOE is "any state-owned corporate entity recognised by national law as an enterprise" (OECD 2014). This includes joint-stock companies, limited liability companies, partnerships limited by shares, and statutory corporations with specific legal form and primarily commercial activities. Each government is entitled to choose the recognition or not of other enterprises as SOEs depending on their judgement, regardless of their degree of market/non-market orientation (OECD 2014). OECD's new perspective concerning SOEs consists of both key elements, such as control and ownership and legal form and activity orientation. 
While OECD defines SOEs from the governance perspective, IPSASB approaches it from the accounting perspective. IPSASB refers to SOEs using the notion "governance business enterprises (GBE)", defined in IPSAS 1 - Presentation of Financial Statements as (IPSASB 2012, 32): "an entity that has all the following characteristics: has the power to contract in its name; has been assigned the financial and operational authority to carry on business; sells goods and services, in the ordinary course of its business, to other entities at a profit or full cost recovery; is not reliant on continuing government funding to be a going concern (other than purchases of outputs at arm's length); is controlled by a public sector entity."

Throughout time, IPSASB developed some projects aiming to set the conceptual delimitation of the term. The first Consultation Paper (CP) idea arose in 2008, but IPSASB discussed and approved a brief project on SOEs in March 2012, which started in December 2012. Initially, IPSASB considered four approaches to SOEs (IPSASB 2012): "(a) Do not specifically define SOEs, but provide the high-level characteristics of entities; (b) Clarify the existing definition of SOEs; (c) Narrow the current definition; or (d) Redefine SOEs using a different approach, e.g., based on services provided by entities or the objectives of entities. But, since it received little support, it was decided not to develop a further approach (d)". Further, in 2014, IPSASB suggests two main approaches. The first approach does not define the term. Instead, it produces a list of characteristics for public sector entities, while the second approach is modifying or narrowing the current definition presented in IPSAS 1. Both approaches have two sub-options; the differentiating criteria are the use of statistical terminology (IPSASB 2014).

One can observe that the IPSASB definition concerning SOEs was initially based mainly on control, ownership, and activity criteria. In 2014, the IPSASB decision was to define SOEs using characteristics and acknowledge the role of regulators in determining other specific elements that could help them establish which entities should be recognized as SOEs (the same approach identified in the OECD project).

European Commission through EUROSTAT provides a definition based on control and ownership criteria, in accordance with OECD: "there are numerous cases of enterprises controlled by the government directly (through nominating its representatives on the board) or indirectly (through state-owned funds and agencies) that themselves control affiliates in another country" (EC, 2012, p. 32). The novelty of definition consists in introducing the notion of direct or indirect control.

Further, the International Monetary Fund (IMF) uses this term in Governance Finance Statistic Manual (GFSM) linking IPSAS and GFSM: "the IPSAS equivalent of a market entity, that is, a GBE" (IMF 2014, 352). The IMF urges international standard-setters to collaborate to align reporting standards for budget, statistics, and accounts.

From the statistical point of view, there are two international frameworks in significant harmony (European System of Accounts - ESA and System National Accounts- SNA). Although terms as GBE or SOE are not used, they refer to corporations and quasi-corporations similar to SOEs when controlled by public sector units (EC 2010; UNSD 2008, SNA, 2008). The concept of control, from a statistical point of view, is "the ability to determine the general policy or programme of that entity" (EC 2010). Corporations are "created for the purpose of producing goods or services for the market that may be a source of profit or another financial gain to its owner(s), being collectively owned by shareholders who have the authority to appoint directors responsible for its general management" (UNSD 2008; EC 2010). Quasicorporations "are unincorporated entities engaged in the production of market goods and 
services, managed as a corporation, having their own set of accounts" (EC 2010; IPSASB 2014; UNSD 2008). SNA and ESA divide public companies into financial and non-financial, depending on their activity (UNSD 2008), and this approach is also identified in the CP provided by IPSASB. However, the approaches of these two international organisations also include, alongside key elements as control, ownership, and activity, a common point of view: the SOEs must have the power to contract in their name, although in certain countries, this cannot be applied, due to national regulations. National accounts statisticians use a rather broad definition of SOEs, including in this type of organisations, all autonomous government companies (ownership criteria) with independent budgets and balance sheets that generate at least half of their income through the commercialisation of goods and services (activity criteria). The national authorities apply a restrictive concept, which is, in many cases, braced in SOE-related legislation (OECD 2014).

World Trade Organisation (WTO) is another international organisation that pays attention to SOEs due to the government's influence on world trade. It refers to SOEs using the term "stateowned transnational companies", and includes in this category all state trading enterprises that deal with goods for export or import (WTO 1994). The definition provided by WTO is not restrictive, and it uses just two key characteristics of SOEs identified in the academic literature: ownership and activity.

World Bank provides the most complex approach among international organisations concerning SOEs' definitions. Despite the SOEs' definition provided in the Glossary of Key Terms being based only on two key elements identified in the academic literature, legal form and activity (commercial), the World Bank created through its toolkit "Corporate Governance of State-Owned Enterprises - a Toolkit" an overview which comprises the majority of the issues identified in the first section of this research paper: areas in which SOEs operate, their importance and role in economies, performance and the ownership and control issues. They assert that these entities are "commercial enterprises that use a distinct legal form and engage in commercial activities and that receive the bulk of their income from sales and fees" (WB 2014). Even if SOEs' definition provided in the Glossary of Key Terms is based only on two key elements identified in the academic literature, legal form and activity (commercial), they created through their toolkit "Corporate Governance of State-Owned Enterprises" (WB 2014), an overview which comprise mostly all issues identified in the first section of this research: areas in which SOEs operate, their importance and role in economies, ownership and control issues. This guideline focuses on commercial SOEs at the national level in which the government has significant control through full, majority, or substantial minority ownership. World Bank concludes that these discrepancies caused by different visions of the countries hamper advancing a generally accepted definition of SOEs.

One conclusion of the study is that the concept of ownership is crucial when defining SOEs. Ownership implies the responsibility for actions regarding the entity, whose rights are usually protected by the law. Also, market and non-market-oriented activities are concepts used by international and professional organizations in defining SOEs. Discussing another significant key element, the notion of control, we identified two approaches analysed among international and professional organizations:

- Policy control - from a statistical perspective, a government exercises control under a corporation if the government can determine the general corporate policy;

- Financial control - from an accounting standpoint, a government controls a company if it has the power to manage its financial and operating policies to benefit from its activities. 
Another conclusion of the study conducted is that international and professional organisations approached the SOE issue from governmental, accounting, or statistical perspectives, providing restrictive definitions based on key elements as ownership, control, and activity (market orientation). OECD, EC, and IPSASB define SOEs using key elements as control and ownership while IMF and UN, activity and ownership. Even if we identified some common approaches between academicians and international and professional organisations, some delicate areas require substantial clarifications.

\section{CONCLUSION}

Based on the definitions presented above, we can conclude that SOEs are public entities controlled directly or indirectly by the government with a mixture of commercial and public policy objectives. SOEs have an adapted legal form, operate in commercial affairs, reach for the achievement of public policy objectives and financial goals.

Even though they are the same companies totally or partially owned by the state, the terminology used differs between countries. There are several different approaches to what types of entities are covered by SOE's definition. The biggest challenge for professional bodies is to find a unique definition to match the need of practitioners and capture the complexity of SOEs.

Overall, the international and professional organisations approach the SOE topic from governance, accounting, or statistical perspectives, based on key elements like ownership, control, market orientation. OECD, EC, and IPSASB define SOEs using key elements as control and ownership while IMF and UN, activity and ownership. Although we have identified some common approaches between international and professional organisations, some delicate areas require laborious efforts for clarifications considering the objective of each organisation. The biggest challenge for professional bodies is finding a unique definition to match all three main areas of interest.

So, we conclude that a definition is necessary. As we saw, significant national professional bodies consider it essential to use a definition, to present the characteristics and provide a guideline for SOE recognition. Emerging countries need to have clearly established boundaries of their financial statements. Most of the time, they do not have the necessary resources as professional bodies, qualified personnel to fulfil their obligations as regulators.

\section{REFERENCES}

Christiansen, H. (2011), "The Size and Composition of the SOE Sector in OECD Countries", OECD Corporate Governance Working Papers, No. 5, OECD Publishing.

European Commission (2012), "EUROSTAT Foreign Affiliates Statistics Recommendation Material, Luxemburg, pp.32.

European Commission (2010) European system of accounts. Luxemburg.

International Monetary Fund (2014), "Government Finance Statistics Manual”, Washington, p. 32.

IPSASB (2012), Handbook of International Public Sector Accounting Pronouncements- Vol I,II, New York, available at: http://www2.ifac.org/publications-resources/2011handbook-international-public-sector-accounting-pronouncements

IPSASB (2014), Responses to GBEs Consultation Paper, New York, available at: http://www2.ifac.org/system/files/meetings/files/GBE\%20\%20responses.pdf 
Kloviene, R., Gimzauskiene, E. (2014), "Performance measurement model formation in stateowned enterprises", Procedia Social and Behavioral Sciences, 156, pp. 954-598.

OECD (2005), Corporate governance of state-owned enterprises: A survey of OECD countries, Paris, OECD.

OECD (2014) OECD guidelines on corporate governance of state-owned enterprises - draft for public comment, OECD, Paris

Papenfuss, U., Schmidt, C. (2015), "Determinants of manager pay in German state-owned enterprises and international public policy implications: 3-years study for sectors, performance and gender", working paper, University of Leipzig, available at: http://hdl.handle.net/10419/107708, (accessed 10 April 2015).

United Nations Statistics Division (2008) System of national accounts. New York

United Nations Statistics Division (2008), System of National Accounts, New York

World Bank (2014) Corporate governance of state-owned enterprises - a toolkit. WB, Washington, DC

World Trade Organisation (1994) The general agreement on tariffs and trade. WTO, Geneva 